\title{
Gender Correlates of Moral Value in Early Childhood
}

\author{
Wiwik Sulistiani ${ }^{1}$, Dewi Mustami' ${ }^{\circ}{ }^{2}$, Dewi Mahastuti ${ }^{3}$ \\ \{wiwik.sulistiani@hangtuah.ac.id ${ }^{1}$, mus_tamiah@yahoo.com² ${ }^{2}$ dewimahastuti77@gmail.com $\left.{ }^{3}\right\}$ \\ Faculty of Psychology, Universitas Hang Tuah, Surabaya, Indonesia
}

\begin{abstract}
The purpose of this study is to examine the differences in dimensions of moral values based on gender. The study is cross-sectional research and using 96 kindergarten students in Surabaya, Indonesia as the subjects. They are consisting of 40 male students and 56 female students. The scale used in this study is the scale of moral values according to the theory by Borba. The result shows that the moral values of empathy, conscience, self-control, respect, kindness, tolerance and fairness do not show significant differences between male and female students. This research shows that male and female students in general do not have any differences about the moral values. Further research still needs to be developed, for example related to the method of moral values education for early childhood, and the influence of family and school on the development of moral values of children.
\end{abstract}

Keywords: Moral Value, Empathy, Kindergarten, Education.

\section{Introduction}

A number of moral cases happened recently. Ironically, some of them are perpetrated by children in early ages. Meanwhile, psychology experts believe that the first five years of a child's life are an important period which will determine their development in later age. The early childhood is termed as the "Golden Age". It is the most critical period to provide educational stimulation, including education of moral value. The golden age is a vital shaping period for the basis of personality, cognitive skill, and social skill which includes moral development [1]. Moral development is not only defined as a knowledge of cultural values, but more about how individuals interact with their social environment [2]. Moral development is a development involving cognition, affection, and behavior pertaining to regulations and conventions on what one should do in a social interaction with others [3]. Child social relations with peer groups are important in learning moral norms and moral development at that age [4]. Moral is defined as individual ability to comprehend truth, to have a strong ethical belief, and to act based on that belief, so they can behave in a kind manner. Moral is built upon seven moral values, including empathy, conscience, self-control, respect, kindness, tolerance, and fairness. Those values are important resources for children to face challenges and lead a moral life in the future [5]. In the study of morality, moral values and gender are among the topics of interest. Many researches on moral concern the masculine and feminine perspectives or focus on moral attitudes according to gender role [6]. Gender role is the expected attitudes and behaviors in life of an individual based on whether they are male or female. It is about how an individual can play their role in accordance with their gender [7]. Gender role attitude might be influenced by many social and cultural stereotypic aspects. It is generally believed that gender roles are learnt in order to act properly in family, community, 
and other social groups. In general, gender ideology seems to be limited to patriarchal ideology which prioritizes masculinity over femininity in almost every environment, including in schools [8]. The results of research on moral development in children show that there are gender differences, girls are more often reported with emotional responses and are more oriented to aspects of emotional behavior than boys. Based on these premises, the questions of this research are:

1. Is there any difference in moral value of empathy between male and female students?

2. Is there any difference in moral value of conscience between male and female students?

3 . Is there any difference in moral value of self-control between male and female students?

4. Is there any difference in moral value of respect between male and female students?

5. Is there any difference in moral value of kindness between male and female students?

6. Is there any difference in moral value of tolerance between male and female students?

7. Is there any difference in moral value of fairness between male and female students?

\section{Method}

\subsection{Participant}

Participants in this research were 96 kindergarten students; 40 of them were male and the other 56 were female aging from five to seven-year-old. The sampling used total population, which implies involving every student in the kindergarten as research participants.

\subsection{Measurement}

\subsubsection{Characteristic Demography}

The demographic data collected in this research was gender (male and female).

\subsubsection{Moral Value}

Moral value was measured using a moral value scale based on Borba's theory of morality. The moral value scale was constructed based on daily moral dilemmas which are commonly faced by children in kindergarten age. This scale consists of seven subscales, namely empathy, conscience, kindness, self-control, self-control, respect, tolerance, and fairness. It comprises 14 items with score range of 1 to 3 . Score 1 describes inappropriate moral values other than what the child is expected to have, score 2 implies appropriate moral value, while score 3 depicts a high moral value compared to the child's age group. A sample item of this scale is "When you see a friend looks confused because he/she lost his/her shoes, what will you do?"

\subsection{Procedure}

Data was collected using a questionnaire. Because the participants were children, the questionnaire was administered via oral interview. Participants were called one by one for the interview guided by questions in the questionnaire. Their responses were recorded and then scored based on a scoring matrix prepared beforehand. The scores ranged from 1, 2, to 3 . Score 1 describes inappropriate moral values other than what the child is expected to have, 
score 2 implies appropriate moral value, while score 3 depicts a high moral value compared to the child's age group. The data collection process took about 30 to 40 minutes per child.

\subsection{Data Analysis}

Data analysis was carried out using SPSS program. The analysis technique was t-test to find score differences in moral values between male and female students.

\subsection{Result}

Below is the result of this research:

Table 1

T-test result

\begin{tabular}{|c|c|c|c|c|c|c|c|c|c|c|}
\hline & & \multicolumn{2}{|c|}{$\begin{array}{l}\text { Levene's Test for } \\
\text { Equality of } \\
\text { Variances }\end{array}$} & \multicolumn{7}{|c|}{ t-test for Equality of Means } \\
\hline & & \multirow[t]{2}{*}{$\mathrm{F}$} & \multirow[t]{2}{*}{ Sig } & \multirow[t]{2}{*}{$\mathrm{t}$} & \multirow[t]{2}{*}{ df } & \multirow{2}{*}{$\begin{array}{l}\text { Sig. (2- } \\
\text { tailed) }\end{array}$} & \multirow{2}{*}{$\begin{array}{l}\text { Mean } \\
\text { Differ } \\
\text { ence }\end{array}$} & \multirow{2}{*}{$\begin{array}{c}\text { Std. } \\
\text { Error } \\
\text { Differ } \\
\text { ence }\end{array}$} & \multicolumn{2}{|c|}{$\begin{array}{l}\text { 95\% Confidence } \\
\text { Interval of the } \\
\text { Difference }\end{array}$} \\
\hline & & & & & & & & & Lower & Upper \\
\hline \multirow[t]{2}{*}{ Empathy } & $\begin{array}{l}\text { Equal } \\
\text { variances } \\
\text { assumed }\end{array}$ & 10.380 & .002 & -2.258 & 94 & .026 & .54643 & .24199 & -1.02690 & .06595 \\
\hline & $\begin{array}{l}\text { Equal } \\
\text { variances } \\
\text { not } \\
\text { assumed }\end{array}$ & & & -2.133 & 65.665 & .037 & .54643 & .25616 & -1.05791 & .03494 \\
\hline \multirow[t]{2}{*}{$\begin{array}{l}\text { Conscien } \\
\text { ce }\end{array}$} & $\begin{array}{l}\text { Equal } \\
\text { variances } \\
\text { assumed }\end{array}$ & .368 & .545 & 1.779 & 94 & .078 & .48929 & .27503 & -.05679 & 1.0354 \\
\hline & $\begin{array}{l}\text { Equal } \\
\text { variances } \\
\text { not } \\
\text { assumed }\end{array}$ & & & 1.829 & 91.193 & .071 & .48929 & .26753 & -.04212 & 1.0207 \\
\hline \multirow[t]{2}{*}{$\begin{array}{l}\text { Self- } \\
\text { control }\end{array}$} & $\begin{array}{l}\text { Equal } \\
\text { variances } \\
\text { assumed }\end{array}$ & .079 & .780 & .344 & 94 & .732 & .08571 & .24931 & -.40930 & .58073 \\
\hline & $\begin{array}{l}\text { Equal } \\
\text { variances } \\
\text { not } \\
\text { assumed }\end{array}$ & & & .340 & 80.847 & .735 & .08571 & .25197 & -.41564 & .58707 \\
\hline \multirow[t]{2}{*}{ Respect } & $\begin{array}{l}\text { Equal } \\
\text { variances } \\
\text { assumed }\end{array}$ & .009 & .924 & -.245 & 94 & .807 & $\begin{array}{r}- \\
.06429\end{array}$ & .26197 & -.58444 & .45587 \\
\hline & $\begin{array}{l}\text { Equal } \\
\text { variances } \\
\text { not } \\
\text { assumed }\end{array}$ & & & -.245 & 83.095 & .807 & $\begin{array}{r}- \\
.06429\end{array}$ & .26289 & -.58716 & .45858 \\
\hline Kindness & $\begin{array}{l}\text { Equal } \\
\text { variances }\end{array}$ & 1.779 & .185 & .372 & 94 & .711 & .08571 & .23030 & -.37155 & .54298 \\
\hline
\end{tabular}




\begin{tabular}{|c|c|c|c|c|c|c|c|c|c|c|}
\hline & assumed & & & & & & & & & \\
\hline & $\begin{array}{l}\text { Equal } \\
\text { variances } \\
\text { not } \\
\text { assumed } \\
\end{array}$ & & & .381 & 90.212 & .704 & .08571 & .22510 & -.36146 & .53289 \\
\hline \multirow[t]{2}{*}{ Tolerance } & $\begin{array}{l}\text { Equal } \\
\text { variances } \\
\text { assumed }\end{array}$ & 1.127 & .291 & .437 & 94 & .663 & .12500 & .28598 & -.44281 & .69281 \\
\hline & $\begin{array}{l}\text { Equal } \\
\text { variances } \\
\text { not } \\
\text { assumed }\end{array}$ & & & .430 & 78.759 & .669 & .12500 & .29089 & -.45402 & .70402 \\
\hline \multirow[t]{2}{*}{ Fairness } & $\begin{array}{l}\text { Equal } \\
\text { variances } \\
\text { assumed }\end{array}$ & 3.469 & .066 & .998 & 94 & .321 & .28929 & .28980 & -.28612 & .86469 \\
\hline & $\begin{array}{l}\text { Equal } \\
\text { variances } \\
\text { not } \\
\text { assumed }\end{array}$ & & & .972 & 75.677 & .334 & .28929 & .29753 & -.30333 & .88191 \\
\hline
\end{tabular}

The result (table 1) shows that there was a difference in empathy score between male and female students with $t=-2.258$ and significance value of $.026, p<0.05$. Male students $(M=$ 4.5250; $\mathrm{SD}=1.19802)$ had higher score of empathy than female students did $(\mathrm{M}=4.0357 ; \mathrm{SD}$ $=1.41375)$. The mean difference between male and female students was 0.4893 , implying that the difference between males and females were only marginal. In moral value of conscience, self-control, respect, kindness, tolerance, and fairness, the significance values were $>0.05$, meaning that there was no difference between male and female students.

\subsection{Discussion}

The result indicates a difference in moral value of empathy between male and female students, but the difference was not remarkable. In other moral values, such as conscience, self-control, respect, kindness, tolerance, and fairness, gender differences were not found. In term of moral development, a child is still in the process of learning to distinguish what is right from what is wrong. In learning moral attitudes, there are four main cornerstones: learning what is expected by the social group, developing conscience, learning to feel remorse and shame when behaving differently from the existing norm, and having opportunities to engage in social interactions in order to learn what is expected by the community [9]. In addition, the stages of gender scheme are as follow: a child learn something which is directly associated with their gender; around four to six year of age, a child starts developing more complex and indirect associations about information which is relevant to their own sex, but not to the opposite sex; and around 8 years of age, a child starts to learn relevant associations of the other sex and understand the concept of gender [10]. The results of research on 6-year-olds also show that gender is not a factor that influences moral development [11]. Gender differences in adults may be the effect of socialization [12]. This implies that kids in early childhood are still in the process of learning morality, they are still in the process of learning to know what is good and what is bad which will be their resources for future social relations.

Acknowledgments This research was financially supported by the Direktorat Riset dan Pengabdian Masyarakat. Direktorat Jenderal Penguatan Riset Teknologi dan Pendidikan 
Tinggi (Grant Number 3 / E / KPT / 2018). We also thank the students and teachers who participated in this study. We also thank students who helped in data collection.

\section{References.}

[1] J. M. Asmani, Manajemen Strategi Pendidikan Anak Usia Dini (PAUD). Yogyakarta: Diva Press, 2009.

[2] L. Kohlberg and R. H. Hersh, "Theory Into Practice Moral development: A review of the theory Moral Development: A Review of the Theory," no. May 2013, pp. 37-41, 1977.

[3] J. W. Santrock, Perkembangan Anak Jilid 2 (Translation: Sarah Genis B), 7th ed. Jakarta: Erlangga, 2011.

[4] Molchanov. S.V, "Moral development in childhood," Procedia - Soc. Behav. Sci., vol. 86, pp. 615-620, 2013.

[5] M. Borba, Membangun Kecerdasan Moral. Jakarta: Gramedia Pustaka Tama, 2008.

[6] C. Gilligan, In A Different Voice: Psychological Theory and Women's Development, no. January 1982. Cambridge, Massachusetts: Harvard University Press, 1982.

[7] D. H. Olson, J. DeFrain, and L. Skogrand, Marriages and Families: Intimacy, Diversity and Strengths, Seventh. New York: Mc. Graw Hill, 2011.

[8] Sultana. A.M, "Patriarchy and Women's Gender Ideology: A Socio-Cultural Perspective A . M . Sultana Department of Malaysian Studies , Faculty of Social Sciences and Humanities ," J. Soc. Sci., vol. 6, no. 1, pp. 123-126, 2010.

[9] Hurlock, Psikologi Perkembangan: Sepanjang Rentang Kehidupan. Jakarta: Erlangga, 1997.

[10] Desmita, Psikologi Perkembangan. Bandung: Remaja Rosdakarya, 2005.

[11] M. B. Johnson, “A Study to Determine The Effects of Moral Development Among Sixth Grade Students Utilizing Kohlberg's Theory of Moral Development and Selected Children's Stories," Memphis State University, 1981.

[12] C. Gilligan, "Woman's place in the man's life cycle," Educ. Fem. Read., vol. 49, no. 4, pp. 26-41, 1979. 